\title{
Community Economic Empowerment Model in Utilizing Local Potential in the Village of Besmarak, Kupang Distric
}

\author{
Heni Matelda Sauw*, Reisanty M. Djami \\ Department of Business Administration \\ Politeknik Negeri Kupang \\ Kupang, Indonesia \\ *Henisauw1703@gmail.com
}

\begin{abstract}
Indonesia is a country that is very rich in resources, both natural and human resources. The wealth of our nation is important in building this nation, among others, by utilizing the available resources to make our country more advanced. In reality, the community is still lacking and access to develop their potential is still difficult, their involvement in supporting the economy is not optimal, they have not been able to utilize, manage and develop the potential of natural resources in their village. This study aims to determine the role of village communities in the utilization of local potential and to find the right model for economic empowerment in Besmarak village, Kupang. This study uses a qualitative descriptive method by describing and interpreting the facts and characteristics systematically appropriately. The subjects in this study were subdistrict officials, village officials, traditional leaders and village communities. Data collection was carried out using the method of observation, interviews and documentation, PRA and FGD. In optimizing the potential of human resources that has been carried out is quite good, this can be seen from the efforts made such as making people aware of their potential, then providing guidance and assistance to the community starting from entrepreneurship training, production skills, and assistance from several parties, the community is given the opportunity to develop what they have got. The purpose of this optimization is from the awareness, capacitating, and empowering stages. It has been going well, from what the community initially ignored and then became an enthusiastic and participating community. In the beginning, many were unemployed and were dominated by people who worked as farmers and farm laborers whose income was uncertain, now almost all of the people worked with enough results to make ends meet. Therefore it is important to build a community self-awareness that every community has the right to enjoy a better life and realizes that where people live, there will also be potential resources available and can be managed properly and used as a support for life. If the community realizes its existence and optimizes it, they have potential that can be developed by being given knowledge, insight, life skills, encouragement, motivation, they will be able to contribute to life and independence for the people of Besmarak village.
\end{abstract}

Keywords-model, local resources, community economic empowerment

\section{INTRODUCTION}

Economic empowerment is currently being carried out seriously as seen from the efforts of the village / village government to make the community the subject and object of development, increase community participation and conduct various kinds of training. Supporting factors in community development in the economic sector include natural resources and abundant human resources in each region [1].

Indonesia is a country that is very rich in resources, both natural resources and human resources. The wealth of our nation is important in building this nation, among others, by utilizing the available resources to make our country more advanced. The economic development of the community is of course something that must be considered, of course in accordance with the potential and capabilities of the community. The community certainly expects better conditions so that the level of welfare can increase, where the needs of life can be met. Therefore, in every community there is a resource which is a potential local which can be used to meet the needs of life.

Our country has different local potential both in terms of human resources and natural resources as well as different ways of managing it. The surrounding resources can be used to improve the welfare of the community. However, if the potential is not properly managed, it is meaningless. This potential wealth should provide abundant benefits for the economic prosperity of the local community. However, in reality the abundant wealth of resources does not provide benefits for the community, because the community's ability to manage and utilize these resources optimally is still low.

Besmarak Village is a village located in Nekamese Subdistrict, Kupang Regency, with the characteristics of rural communities. This village has abundant natural resource potential, where many coconut plants can be processed into economically valuable products. Currently, the use of coconut fruit is more developed. One of them is by making it into Virgin Coconut Oil (VCO). According to several studies, VCO has many benefits compared to ordinary coconut oil, among 
others it is believed to be effective in eradicating various diseases.

However, it is not an easy thing to make people aware of the abundant potential so that it can be used to improve the community's economy and be motivated to learn to manage coconut fruit for VCO, because people still think that their livelihoods are farming and raising more money to support their lives.

This study aims to determine the role of village communities in the utilization of local potential and to find the right model for economic empowerment in Besmarak village, Kupang.

\section{LITERATURE REVIEW}

\section{A. Model}

A model is a representation, pattern, reference of an object, object, or ideas in simplified form. A model contains information about a phenomenon created with the aim of studying the actual system phenomenon. A model can be an imitation of an actual object, system or event which only contains information that is considered important to be studied [2].

\section{B. Local Resources}

In the Indonesian dictionary, it is found, the meaning of "resource", namely "everything, both tangible and intangible, which is used to achieve results". Local resources are everything that is in our local area, or locally, which can be used to achieve a common goal, so it can be said that a resource must have two criteria, the first is that there must be knowledge, technology or skills to use it. There is a demand for these resources [3]

Locality-based empowerment is a process of efforts to strengthen community capacity by directing assets in the local community to meet their needs. Efforts to use local resources that exist in the local environment are used as a method or learning resource for empowering rural women. This is intended so that activities can match the interests and needs of the local community by originating from the wealth of the local environment.

\section{Community Economic Empowerment}

Empowerment has the meaning of a process to be effective so that it can change society for a better life situation. According to Sumardjo [4], community empowerment is a process of developing opportunities, willingness / motivation, and the ability of people to have access to resources, thereby increasing their capacity to determine their own future by participating in influencing and realizing the quality of life for themselves and their communities. In the Law on Villages Number 6 of 2014 point 12 it is stated that Village Community Empowerment is an effort to develop community independence and welfare by increasing knowledge, attitudes, skills, behaviour, abilities, awareness, and utilizing resources through the establishment of policies, programs, activities, and assistance in accordance with the essence of the problem and the priority needs of the village community. Meanwhile, according to Widjaja [5], it is explained that the essence of empowerment is an effort to awaken all existing village capabilities to achieve goals. The achievement of goals is carried out through the growth of motivation, initiative and creativity to advance.

Community economic empowerment implies the economic development of the majority of Indonesians as the main agenda for national development so that concrete steps must be taken so that the economic growth of the community takes place quickly. With the existence of community economic empowerment, it is hoped that it can improve people's lives in a better direction [6]. A better community life basically includes the necessities of life, the need for self-esteem, and the need for freedom [7]. Therefore, economists argue that the goal of community economic empowerment must prioritize absolute needs, minimum requirements to meet basic and basic needs. Empowerment refers to the ability of a person, especially weak community groups, to have access to productive sources that enable them to increase their income and obtain the goods and services needed and participate in the development process and decision-making that affect them.

\section{RESEARCH METHODS}

When viewed from the type of place where the research is carried out, this research is classified as field research or field research, namely research that has the aim of collecting data and information about certain problems regarding the life of the people that are the object of research. This study uses a qualitative approach perspective. In general, qualitative research can be used for research on community life, history, behavior, organizational functionalization, social activities, etc. In this study the authors used a qualitative approach method in identifying problems related to empowerment models. Community economy in the utilization of local potential because qualitative methods are developed to study humans in certain cases [8].

The selection of the research area was carried out purposively which was the reason for determining the research area in order to reveal about the use of rural local resources by the village community. The sample selection of the research area was carried out after making observations then determined 3 hamlets from 5 hamlets in the village area of Besmarak, Nekamese sub-district, Kupang Regency.

The data analysis technique used is descriptive method, namely a method that describes and interprets the research object as it is. The results of the report describe the state of the object or subject under study or describe the state of the object or subject under study.

\section{RESULTS AND DISCUSSION}

To achieve the research objectives used descriptive analysis methods, namely methods that describe and interpret the 
research object as it is. The results of the report describe the state of the object or subject under study or describe the state of the object or subject under study.

Besmarak Village is included in the original category where the basic needs problem is a village / kelurahan that requires priority handling of problems of meeting basic needs such as economy, education, health, infrastructure, and the environment. This is because, even though the development is carried out structurally, in its implementation it still has not given optimal results because understanding of the condition of the community internally still supports development plans [9]. Based on the results of interviews, observations, and documentation by the writer, the writer illustrates that Besmarak Village is an area that still needs village development, where the most human resources in the village are women and are dominated by children and adults and the elderly, based on adolescence and Village youths are also men, many of whom have migrated or studied in the cities.

Seeing this fact, it requires efforts from the government and the community to empower themselves and their villages for the sake of realizing community welfare. Realizing this business requires strong efforts from both the community and the local government in removing restrictions such as lack of economic opportunities, poverty and neglected facilities [10]. The effort in question is to carry out community empowerment as an effort to provide strength or power to the community so that it can get out of the problems at hand. Community empowerment allows change by relying on the ability, initiative and participation of the village community itself. Community economic empowerment implies the economic development of the majority of Indonesians as the main agenda for national development so that concrete steps must be taken so that the economic growth of the community takes place quickly. With the existence of community economic empowerment, it is hoped that it can improve people's lives in a better direction.

From the level of education, according to several informants most of the people in the village were junior high school graduates. This indicates that they must be given strengthening skills in order to develop themselves. In order to support their economy. This coaching is carried out simultaneously, integrated and thoroughly and continues to achieve the expected targets, in the form of psychological goals (intelligent, critical, creative, proactive, disciplined, never give up and have a sense of pride as citizens) and physical goals (strong, agile and skilled) [11]

The human resources based on livelihood are farmers, breeders, traders and VCO makers. This was confirmed by the results of interviews with several resource persons such as the village head, village secretary, RT and village facilitators who stated that the expertise of the people in Besmarak Village was farming and making VCO. Seeing the available natural resource capital, namely the coconut plant which dominates the village area, it is necessary to provide assistance and guidance in order to maximize the existing potential. This needs to be developed in order to compete with the economies of other villages as an effort to empower the community in increasing efficiency and productivity through the empowerment of existing resources.

The stages carried out by community empowerment pioneers, in this case the village government and large village facilitators, in optimizing local potential through the manufacture of virgin coconut oil (VCO) to improve the economy of large rural communities, namely by using the following empowerment stages:

\section{A. Awareness Stage}

At this stage the village government and facilitators hold a meeting with residents and try to invite the community to make virgin coconut oil (VCO) made from coconut as raw material available in their village. The meeting was held aimed at making people aware of its potential and trying to develop it. After carrying out these stages, the village government and facilitators can make the community aware through chats and meetings to invite them and make the community aware of the potential of each community. Even so, the response received from the public was not that they all wanted to participate, only a few wanted to participate.

\section{B. Capacity Building}

This stage consists of three types of capacity, namely human capacity, organization and value systems. Human capacity is carried out by providing skills and other activities to improve individual or group skills. Organizational capacity building was carried out by conducting training held by the village government, village community empowerment facilitators in Besmarak and the Kupang Regency Industry and Trade Office. The training was held after many people were interested and interested in learning to make virgin coconut oil (VCO). Without realizing it, efforts to persuade local residents to produce results and without realizing it have also influenced other residents to join in the business. At this stage the community is given training to further optimize the existing potential. In training in the form of mentoring and coaching such as entrepreneurial management training, production skills, equipment assistance, capital. As time goes by, more and more residents are willing to learn to make VCO, even the village government continues to strive to help and foster those who are willing and willing to learn and provide moral and material assistance so that they can continue to optimize the potential of their community.

\section{Empowerment}

At this stage the community is given the opportunity or authority to use the knowledge, skills and abilities they already have to manage and develop themselves. After the community was enlightened by facilitators and other parties, they began to develop and were able to make VCO and market it. Some of the efforts that have been made by several parties to optimize the potential of human resources have been embedded in every Besmarak Village community. They started to dare to be 
independent and slowly started their own VCO production business.

Based on the results of interviews conducted by the author with the village government and village community empowerment facilitators regarding the skills provided to optimize the potential of existing resources through the manufacture and marketing of virgin coconut oil (VCO), the people of Besmarak village have been in the business of making virgin coconut oil for a long time. 5 years since 2015 . From the results of interviews and explanations from the facilitators, now almost all people in Besmarak Village are producers of virgin coconut oil. The response from the community has had a positive impact because they have been greatly helped by this effort.

In optimizing the potential of human resources that has been carried out is quite good, this can be seen from the efforts made such as making people aware of their potential, then providing guidance and assistance to the community starting from entrepreneurship training, production skills, and assistance from several parties. Who also help to maximize this potential, and the community is given the opportunity to develop what they have got. So that people are able to make their own crafts. The purpose of this optimization is from the awareness, capacitating, and empowering stages. It has been going well, from what the community initially ignored and then became an enthusiastic and participating community. In the beginning, many were unemployed and were dominated by people who worked as farmers and farm labourers whose income was uncertain, now almost all of the people worked with enough results to make ends meet. Therefore it is important to build a community self-awareness that every community has the right to enjoy a better life and realizes that where people live, there will also be potential resources available and can be managed properly and used as a support for life. If the community realizes its existence and optimizes it, they have potential that can be developed by being given knowledge, insight, life skills, encouragement, motivation, they will be able to contribute to life and independence for the people of Besmarak village (See Figure 1).

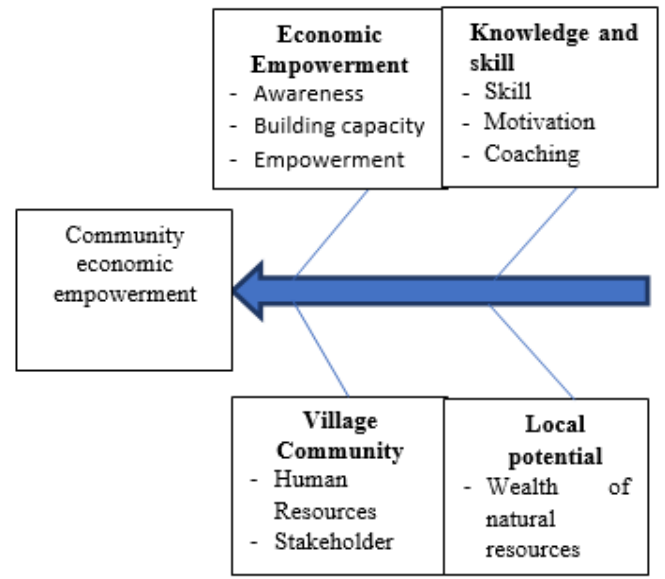

Fig. 1. Community economic empowerment model.

\section{CONCLUSION}

Based on the discussion above, it can be concluded that:

- The application of the community empowerment model must involve all stakeholders in order to be effective.

- The stages in community economic empowerment include (a) empowerment in terms of awareness, encapsulation and community building; (b) Knowledge and skills as well as motivation; (c) local village potential; (d) village communities with human resources as well as stakeholders.

\section{REFERENCES}

[1] M. Murdani and H. Hadromi, "Pengembangan Ekonomi Masyarakat Melalui Pemberdayaan Usaha Mikro Kecil dan Menengah (Studi di Kelurahan Kandri Kecamatan Gunungpati Kota Semarang), Jurnal Abdimas, vol. 23, no. 2, pp. 152-157, 2019.

[2] M. Achmad, Simulation and Modeling Techniques. Yogyakarta: Gajah Mada University, 2008.

[3] A. Fauzi, Sustainable development in Indonesia. Bogor, 2008.

[4] Sumardjo, Kepemimpinan dan Pengembagan Kelembagaan Pedesaan. Kasus Kelembagaan Ketahanan Pangan, Penyunting Ida Yustina dan Ajad Sudrajat. Bogor: IPB Press, 2003.

[5] Widjaja, Otonomi Daerah dan Daerah Otonom. Jakarta: PT. Raja Grafindo Persada, 2011

[6] C. Rintuh dan Miar, People's Institutional and Economic. Yogyakarta: BPFE, 2005.

[7] Suryana, Development Economics: Problems and Approaches. Jakarta: Pustaka Pelajar, 2006

[8] Sugiyono, Quantitative Research Methods, Qualitative and R\&D. Bandung: Rosda Karya, 2010

[9] K. Sinaga, S. Lubis, M. Sihombing, and R.F. Dalimunthe, "Tourism Object Development in Samosir Regency, Indonesia," Budapest International Research and Critics Institute (BIRCI-Journal): Humanities and Social Sciences, vol. 1, no. 3, pp. 91-104, 2018.

[10] L.E. Garkovich, "A historical view of community development," Introduction to community development: Theory, practice, and servicelearning, pp. 11-34, 2011.

[11] T. Siahaan, Tataran Dasar Bela Negara. Jakarta: Kementerian Pertahanan RI, 2014. 